\title{
Chilean Salmon Sushi: Genetics Reveals Product Mislabeling and a Lack of Reliable Information at the Point of Sale
}

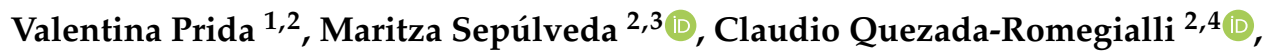 \\ Chris Harrod ${ }^{2,5} \oplus^{\circ}$, Daniel Gomez-Uchida ${ }^{2,6} \mathbb{D}$, Beatriz Cid $^{2,7}$ \\ and Cristian B. Canales-Aguirre 1,2,*iD \\ 1 Centro i mar, Universidad de Los Lagos, Puerto Montt 5480000, Chile; vpridag@gmail.com \\ 2 Núcleo Milenio de Salmónidos Invasores (INVASAL), Concepción 4030000, Chile; \\ maritza.sepulveda@uv.cl (M.S.); claudio.quezada@upla.cl (C.Q.-R.); chris@harrodlab.net (C.H.); \\ dgomezu@udec.cl (D.G.-U.); beatrizcid@udec.cl (B.C.) \\ 3 Centro de Investigación y Gestión de Recursos Naturales (CIGREN), Instituto de Biología, \\ Facultad de Ciencias, Universidad de Valparaíso, Playa Ancha, Valparaíso 2340000, Chile \\ 4 Departamento de Biología, Facultad de Ciencias Naturales y Exactas, Universidad de Valparaíso, \\ Playa Ancha, Valparaíso 2340000, Chile \\ 5 Instituto de Ciencias Naturales Alexander von Humboldt, Universidad de Antofagasta, \\ Antofagasta 1271155, Chile \\ 6 Departamento de Zoología, Facultad de Ciencias Naturales y Oceanográficas, Universidad de Concepción, \\ Concepción 4070032, Chile \\ 7 Departamento de Sociología, Facultad de Ciencias Sociales, Universidad de Concepción, \\ Concepción 4070032, Chile \\ * Correspondence: cristian.canales@ulagos.cl; Tel.: +56-65-232-2459
}

Received: 19 October 2020; Accepted: 16 November 2020; Published: 19 November 2020

check for updates

\begin{abstract}
Species diagnosis is essential to assess the level of mislabeling or misnamed seafood products such as sushi. In Chile, sushi typically includes salmon as the main ingredient, but species used are rarely declared on the menu. In order to identify which species are included in the Chilean sushi market, we analyzed 84 individual sushi rolls sold as "salmon" from sushi outlets in ten cities across Chile. Using a polymerase chain reaction-restriction fragment length polymorphism protocol (PCR-RFLP), we identified mislabeled and misnamed products. Atlantic salmon was the most common salmonid fish used in sushi, followed by coho salmon, rainbow trout, and Chinook salmon. We found a total of $23 \%$ and $18 \%$ of the products were mislabeled and misnamed, respectively. In $64 \%$ of cases, the salesperson selling the product could not identify the species. We also identified the use of wild-captured Chinook salmon samples from a naturalized population. Our results provide a first indication regarding species composition in Chilean sushi, a quantification of mislabeling and the level of misinformation declared by sales people to consumers. Finally, considering that Chinook salmon likely originates from a non-licensed origin and that sushi is an uncooked product, proper identification in the food production chain may have important consequences for the health of consumers.
\end{abstract}

Keywords: cyt b; DNA authentication; fish; aquaculture; salmonids; mislabeled; misnamed

\section{Introduction}

The globalization of cuisine has led to rapid and marked changes in how humans consume food, with the consumption of seafood tripling worldwide in the last decade [1], supported by a rapid growth 
in aquaculture. Human consumption of cultured salmonids (salmon and trout) became increasingly popular [1], especially with regard to salmon, which is seen by many people worldwide as a healthy food choice [2]. Additionally, aquaculture has become a subject of public concern due to issues of environmental impact, human health, and fish welfare [3]. This fuels a demand for alternative seafood networks that offer wild, organic, or fair-trade products [4-6]. Although the seafood list published by the U.S. Food and Drug Administration [7] includes guidance regarding acceptable market names to identify particular species, the market names of common and widely consumed species can be vague. This is particularly common among products derived from salmonid fishes, which are often labeled as "salmon"; however, a number of different species of the genera Oncorhynchus and Salmo fall under this label, showing a lack of species-specific market names for salmonid fishes.

Chile is the second largest aquaculture producer of salmonid fishes worldwide, exceeding 880,000 tons production in 2018 [8,9]. Currently, Atlantic salmon (Salmo salar) dominates production in Chile (2018 production: 661,138 tons live weight) followed by coho salmon (Oncorhynchus kisutch: 148,521 tons), and rainbow trout (Oncorhynchus mykiss: 78,446 tons) [8]. Although the bulk of Chile's salmonid production is exported, these three cultured species can also be sold nationally following statutory requirements [9]. In addition to aquaculture fish, Chile also supports widespread and abundant populations of naturalized salmonid fishes, where the entire life cycle is completed as free-living individuals [10] including rainbow trout, Chinook salmon (Oncorhynchus tshawytscha), and brown trout (Salmo trutta) [11-14]. There is evidence that such naturalized populations could make significant contributions to commercial services supporting human consumption (e.g., Chinook salmon), but the scale or geographical distribution of services for these species provide is unclear. Moreover, at a local level, there is no information available regarding how these species enter the human food chain. As products from non-formal trade are by definition outside of the public health system, they do not have the relevant certifications from health authorities. Although fish originating from naturalized populations may be preferred by some people due to perceived increased quality (e.g., without antibiotics and other chemical treatments), their supply and sale for human consumption is illegal in Chile (except for only Chinook salmon from Toltén River) if they lack any certification from public health authorities regarding their health status or origin.

Correct species identification in the food supply system is crucial as it promotes trust and customer confidence [15]. Chilean food labeling regulations require that species names should be included in ingredient lists (Chilean Ministry of Health). However, this is not always followed by food suppliers. Within the global food sector, seafood from both capture fisheries and aquaculture is associated with the highest rates of mislabeling (i.e., where the product is sold as being from another species or source either intentionally or unintentionally) [16]. A high rate of seafood mislabeling has been identified in restaurant and catering services $[17,18]$. Intentional mislabeling typically occurs as a fraudulent attempt to pass a product of known lower value as one with higher value $[17,19,20]$. Mislabeling can also occur unintentionally due to factors not directly related to profit including inadequate or confusing labeling regulations, fisheries targeting similar species, and informal or illicit production chains [21,22]. For instance, the taste and texture of fish flesh can be very similar, making them difficult to discriminate at a species level [23], increasing the likelihood of mislabeling. Additionally, processing removes the morphological characteristics typically used to discriminate between species (i.e., head, skin and fins), and it is almost impossible to identify species from fillets. Such fraud or mis-supply can permanently damage product reputation, especially if human health is impacted by the consumption of fraudulent products mis-sold as genuine [19]. Otherwise, from the point of view of small producers and local communities, although labeling may represent an opportunity to access specialty markets (e.g., organic and fair trade), it also involves important cost and bureaucratic barriers that are difficult to overcome [24]. This results in informal markets where fraud is possible, but can also lead to high-quality local products not being correctly labeled and therefore do not receive the economic premium permitted by the certification processes. 
Globally, Asian cuisine is popular with consumers: sushi being one of the most common ways by which seafood is consumed. Originating in Japan, this dish has undergone a massive global boom during the last decade [25], and is particularly popular in Latin America, where recipes have been modified to reflect local materials and consumer preferences. This has resulted in an increase in the number of Japanese restaurants in the region; meanwhile, other non-Japanese restaurants have diversified their menus to include Japanese food [26]. Sushi can include a number of ingredients, but a popular option includes raw fish. The fish species varies by recipe, nonetheless, this type of cuisine is one of the most affected with mislabeling, with salmon, tuna, halibut, and red snapper being the most mislabeled and substituted species [27-29]. This has led to a number of different tools being developed to correctly identify the species sold as sushi.

Several techniques exist to allow the identification of species or origin (naturalized versus cultured) including analyses of fatty acids, stable isotopes, carotenoids, and specific protein profiles [30-33]. However, molecular genetic techniques have many advantages for the identification of processed and unprocessed food as they take advantage of the composition and the conserved regions of the DNA between species and even between populations [34-37]. A wide variety of DNA-based methods exist for identification including direct sequencing of DNA fragments [38], single nucleotide polymorphisms [39], and digestion of an amplicon by endonucleases [40]. The latter is the least costly and most straightforward to use as it does not require expensive equipment or highly skilled molecular laboratory staff.

In order to identify the species origin of "salmon" sold in the Chilean sushi market, we used a polymerase chain reaction-restriction fragment length polymorphism (PCR-RFLP) protocol on $\mathrm{a} \sim 460 \mathrm{bp}$ cytochrome $\mathrm{b}$ gene fragment (cyt $\mathrm{b}$ ) of mitochondrial DNA to be compared with positive controls of salmonids present in Chile (i.e., cultured and naturalized). Specifically, we used the DdeI restriction enzyme for species identification given its capacity to reliably produce specific restriction patterns in fishes including salmonids [41,42]. Specific band patterns for S. salar (350 and $130 \mathrm{bp}$ ), O. mykiss (360 and $130 \mathrm{bp}$ ), O. kisutch (300, 130, and $60 \mathrm{bp}$ ), and O. tshawytscha (300 and $220 \mathrm{bp}$ ) were reported by Russell et al. [40] and Hold et al. [43].

We refer to mislabeling where sushi rolls offered on the menu at the point of sale were sold under the generic name of "salmon" (without a species name provided in the menu) but were genetically identified as trout. We refer to Atlantic salmon, coho salmon, Chinook salmon, as salmon, and rainbow trout as trout. We also conducted a small-scale survey to assess knowledge levels regarding salmonid species that are sold in Chile and to identify specific names provided at the point of sale, and these data were subsequently used to estimate the substitution rates. We use the term misnaming to refer to any information declared by the salesperson at the point that did not match the molecular identification. We found a total of $23 \%$ mislabeled and $18 \%$ misnamed products: $64 \%$ of salespeople were unable to identify the species they were selling to customers. We also identified the use of wild-captured Chinook salmon samples from a naturalized population. Our results provide a first indication regarding species composition in Chilean sushi, a quantification of mislabeling and the level of misinformation declared by sales people to consumers.

\section{Materials and Methods}

\subsection{Sample Collection and Survey}

Between January 2019 and January 2020, we collected 84 salmonid sushi rolls from premises selling sushi (one roll per each sushi place, i.e., restaurants or take away) from ten different cities located across Chile (Figure 1). Specifically, we collected salmonid sushi roll as samples from five or more different premises selling sushi from each city, except for the city of Quellón. These cities are located along a $3000 \mathrm{~km}$ latitudinal gradient extending from the arid north through to the center of salmon aquaculture in the south of Chile. A small sample of uncooked muscle tissue was taken from each sushi roll and frozen at $-20{ }^{\circ} \mathrm{C}$. At the point of sale, key characteristics were recorded 
including the trading name of the premises, purchase date, location, and sushi type: these data are not included further in the analyses reported here. We also asked salespeople what species was provided in the sushi. Finally, we collected samples of the main species of salmonids present and consumed in Chile (Atlantic salmon, coho salmon, Chinook salmon, and rainbow trout), both cultured or naturalized for use as positive controls for genetic analyses.

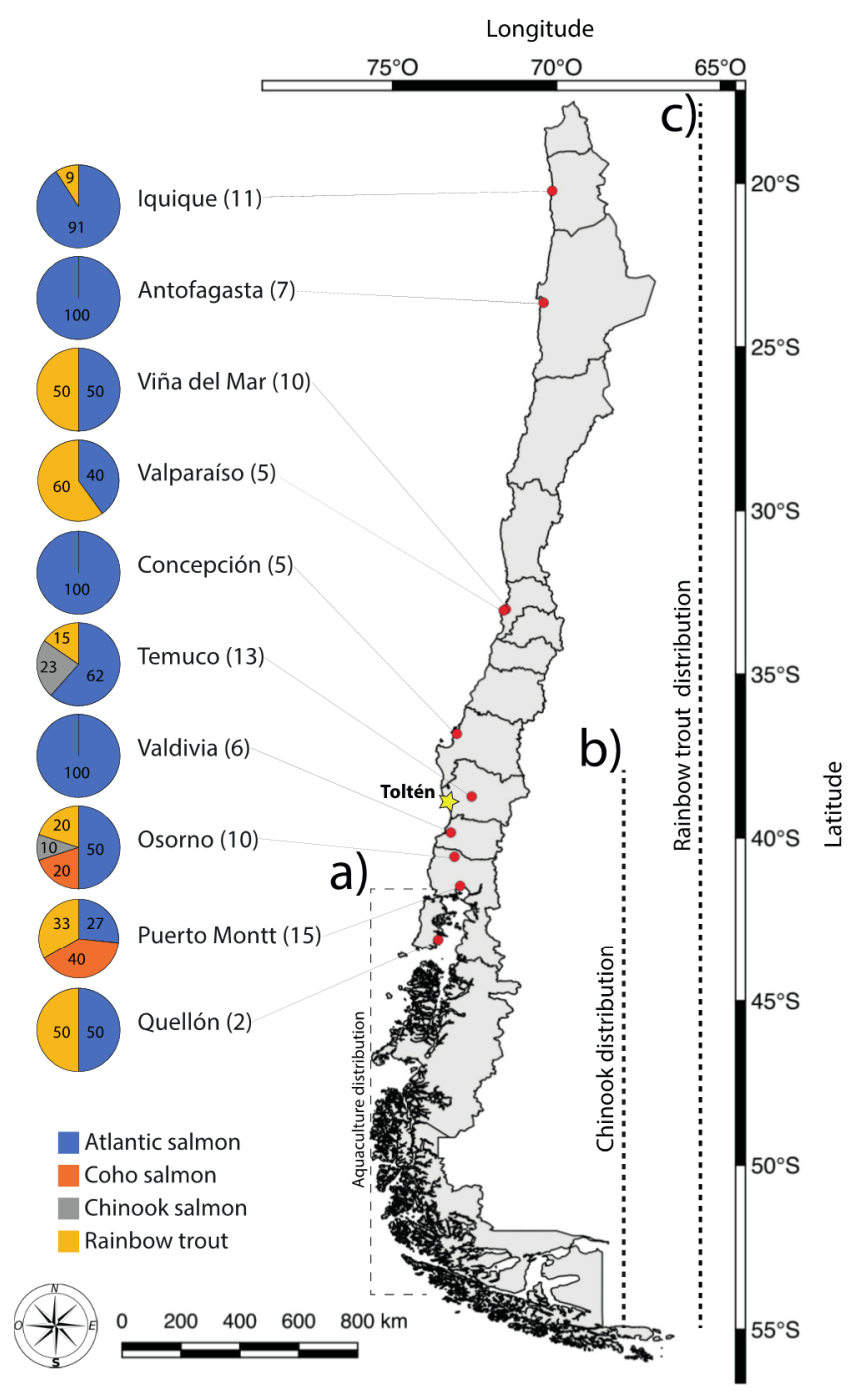

Figure 1. Sampling locations and proportion of sushi samples identified to four different salmonid species based on PCR-RFLP (polymerase chain reaction-restriction fragment length polymorphism). Red markers show the cities where samples were collected, and the yellow marker shows the location of the legal Chinook salmon fishery. Numbers in parentheses reflect the sample size of premises selling sushi in each city, while numbers inside the pie show the percentage. Broken lines show the parts of Chile where (a) salmonid aquaculture is common, and (b) Chinook salmon and (c) rainbow trout have naturalized populations.

\subsection{Molecular Procedures}

Genomic DNA of each piece of tissue was extracted using the salting-out protocol [44]. We used the L14735 and H15149 primers described by Burgener [42] to amplify a fragment of the mitochondrial cytochrome $b$ gene (cyt b, $460 \mathrm{bp}$ ). PCR amplifications were performed in a final volume of $50 \mathrm{uL}$ containing 10X Buffer PCR, $25 \mathrm{mM} \mathrm{MgCl}_{2}, 2.5 \mathrm{mM}$ dNTP's, $10 \mu \mathrm{M}$ of each primer, $1 \mathrm{U} / \mu \mathrm{L}$ Taq DNA polymerase (Invitrogen ${ }^{\mathrm{TM}}$, Carlsbad, CA, USA), and $10 \mathrm{ng} / \mu \mathrm{L}$ of genomic DNA. The amplification program considered a cycle at $94^{\circ} \mathrm{C}$ for $5 \mathrm{~min}$, followed by 35 cycles at $94{ }^{\circ} \mathrm{C}$ for $20 \mathrm{~s}, 52^{\circ} \mathrm{C}$ for $20 \mathrm{~s}$, and $72{ }^{\circ} \mathrm{C}$ for $20 \mathrm{~s}$, and a final extension at $72{ }^{\circ} \mathrm{C}$ for $7 \mathrm{~min}$. We followed the protocol for PCR-RFLP 
analysis described by Hold et al. [43], which included 10X buffer Tango and 3 units of DdeI restriction enzyme (Invitrogen ${ }^{\mathrm{TM}}$, Carlsbad, CA, USA) incubated at $37^{\circ} \mathrm{C}$ overnight. Finally, we visualized the RFLP cutting patterns on a 3.0\% agarose gel run in an electrophoresis chamber for $90 \mathrm{~min}$ at $95 \mathrm{~V}$ under a Safe Imager 2.0 Blue-Light Transilluminator System (Invitrogen ${ }^{\circledR}$, Carlsbad, CA, USA).

\subsection{Data Analysis}

To support the specificity of the restriction enzyme DdeI, we conducted an in-silico RFLP using sequences of cyt $b$ obtained from GenBank. We downloaded all sequences that included the cytb gene for each species. We then found and extracted the exact amplicon fragment ( 463 bp) flanking the primers L14735 and H15149 in one full mitochondrial genome per species (S. salar, JQ390056; O. kisutch, EF126369; O. mykiss, MT410879; O. tshawytscha, NC_002980). We used this amplicon fragment as a reference to align the remaining sequences obtained from GenBank: alignments were conducted using the software MUSCLE v3.8 [45]. During the alignment by species process, sequences larger than 463 were trimmed to this size, sequences shorter than $400 \mathrm{bp}$ were discarded, and we kept a maximum of 20 records per species for visualization purposes. These steps resulted in a final sequence dataset of 71 sequences (Table S1). Finally, we aligned all fragments for all species included in this study for the in-silico RFLP analysis conducted in CodonCode Aligner (CodonCode Corp., Dedham, MA, USA).

We compared the molecular results obtained by PCR-RFLP in each premises selling sushi with the information declared by salespeople. Samples were considered as mislabeled when the molecular species identification as trout did not match the "salmon" name provided at the point of sale. Additionally, they were considered misnamed when the information declared at the point of sale did not match the molecular identification.

\section{Results}

\subsection{PCR-RFLP as a Molecular Diagnosis Tool}

All samples showed a successful amplification of the cyt $b$ fragment ( 460 bp) with unique PCR-RFLP profiles for each salmonid species. The restriction enzyme DdeI produced an approximate cut pattern of two bands of 320 and $115 \mathrm{bp}$ for Atlantic salmon, three bands of 260, 115, and $70 \mathrm{bp}$ for coho salmon, two bands of 340 and $115 \mathrm{bp}$ for rainbow trout, and finally two bands of 280 and $160 \mathrm{bp}$ for Chinook salmon (Figure 2). The in-silico RFLP analysis using sequences from GenBank showed the same restriction cut pattern found in our results (Figure S1).

\subsection{Salmon and Trout Identification, Mislabeling, and Misnaming}

All sushi rolls were sold as including "salmon" as a main ingredient, but none identified what species of salmon this referred to. Out of the 84 samples examined, our molecular diagnosis showed that $63 \%$ were Atlantic salmon $(n=53), 23 \%$ rainbow trout $(n=19), 10 \%$ coho salmon $(n=8)$, and $5 \%$ Chinook salmon $(n=4)$. In terms of geographical distribution, sushi containing Atlantic salmon was found in each of the ten different cities sampled. Sushi containing rainbow trout was found in eight of the ten cities, but not in Valdivia or Concepción (Figure 1). Coho salmon was recorded from Puerto Montt and Osorno. Chinook salmon was only identified in sushi from the cities of Temuco and Osorno (Figure 1).

Each of the premises that we visited identified their sushi as containing "salmon" in their menu. As such, we did not expect that samples would include rainbow trout. However, in our sample of Chilean sushi suppliers, we showed a $22.6 \%$ mislabeling rate, and this extended to seven of the ten cities we collected samples in (Figure 3). Within a given city, mislabeling rates ranged from $9 \%$ (Iquique) to $60 \%$ (Valparaiso). When controlled for sample size, mislabeling ranged from 1\% (Iquique and Quellón) to $6 \%$ (Viña del Mar and Puerto Montt). 


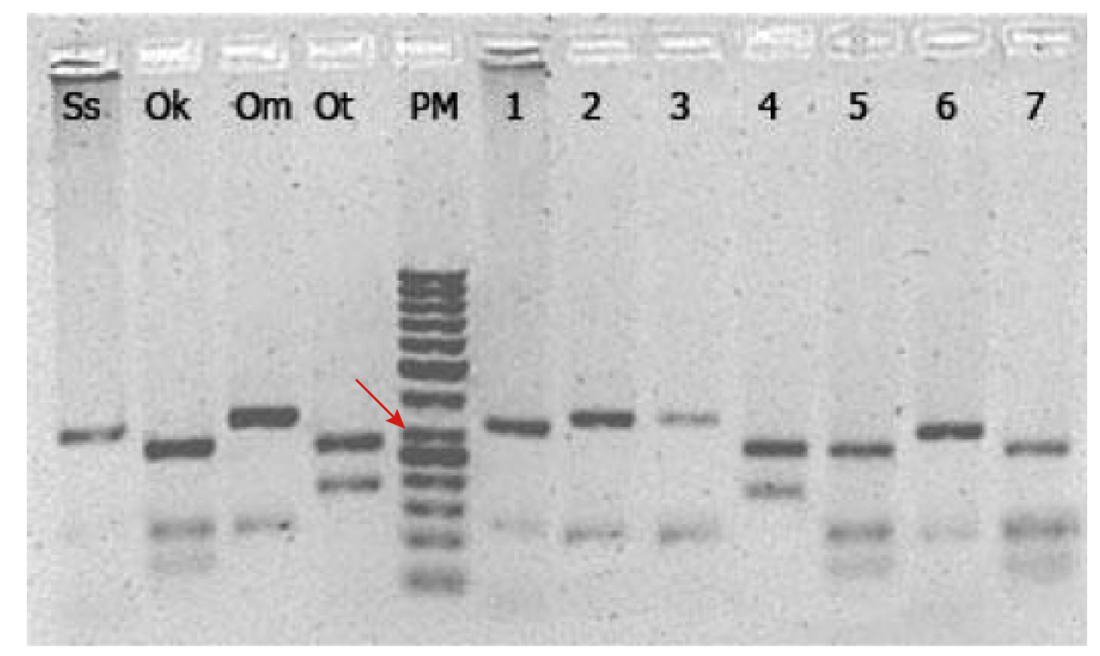

Figure 2. PCR-RFLP analysis of the mitochondrial cytochrome b gene amplified and digested using DdeI. Ss: Salmo salar (Atlantic salmon), Ok: Oncorhynchus kisutch (Coho salmon), Om: Oncorhynchus mykiss (Rainbow trout), Ot: Oncorhynchus tshawytscha (Chinook salmon), PM: molecular ladder $100 \mathrm{bp}$. Numbers from 1 to 7 correspond to an arbitrary subset of samples obtained in the sampling collection at different premises selling sushi. The red arrow indicates the $300 \mathrm{bp}$ band.

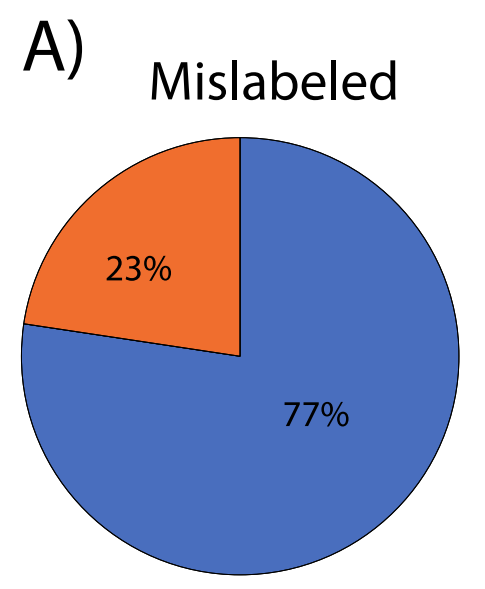

Mislabeled / Misnamed
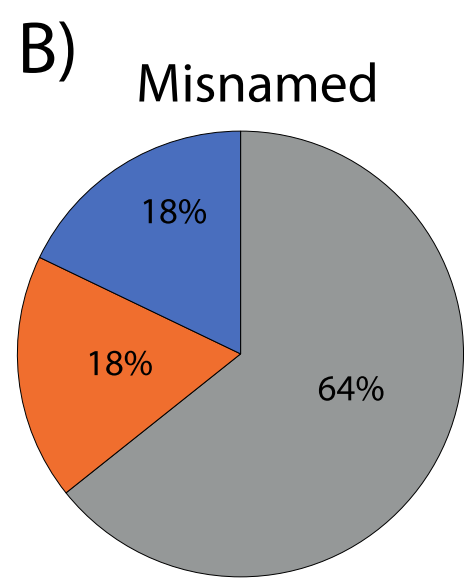

Match
Does not know

Figure 3. Percentage of Chilean salmonid sushi samples either (A) mislabeled (19 of 84) or (B) misnamed (15 of 84) when considering all samples collected $(n=84)$.

With regard to misnaming, $64 \%(n=54)$ of staff surveyed at the point of sale were unable to state what species of salmon they were supplying, conversely, 36\% $(n=30)$ did provide a species name (Figure 3, Table 1). However, in 50\% of such cases (18 of 36), our genetic results showed that they incorrectly identified (i.e., misnamed) the species (Figure 3; Table 1). No sushi supplier identified Chinook salmon as an ingredient of their sushi rolls, while four restaurants stated their product was "salmon-trout" (Table 1, Table S2), which in some countries is referred to as anadromous brown trout, or sometimes lake trout with a silver phenotype (e.g., United Kingdom) [46]. 
Table 1. Number of responses from salespeople to the question “What species was provided in the sushi?" asked by researchers when purchasing 'salmon'-based sushi in cities across Chile. Species not identified reflects responses where salespeople would/could not provide an answer. Species identification provided reflects the number of cases where salespeople provided information on the species of salmon.

\begin{tabular}{|c|c|c|c|c|c|c|c|c|}
\hline \multirow[b]{2}{*}{ Locality } & \multicolumn{2}{|c|}{ (A) Salesperson Response } & \multicolumn{6}{|c|}{ (B) Species Identification Provided } \\
\hline & Species Not Identified & Species Identification Provided & Atlantic Salmon & Rainbow Trout & Coho Salmon & Salmon-Trout & Species Correctly Named & Species Misnamed \\
\hline Iquique & 11 & 0 & & & & & - & - \\
\hline Antofagasta & 6 & 1 & 1 & & & & 1 & 0 \\
\hline Concepción & 5 & 0 & & & & & - & - \\
\hline Viña del Mar & 8 & 2 & 2 & & & & 1 & 1 \\
\hline Valparaíso & 3 & 2 & 2 & & & & 1 & 1 \\
\hline Temuco & 11 & 2 & 2 & & & & 2 & 0 \\
\hline Valdivia & 2 & 4 & 2 & & 1 & 1 & 2 & 2 \\
\hline Osorno & 2 & 8 & 6 & 1 & & 1 & 5 & 3 \\
\hline $\begin{array}{l}\text { Puerto } \\
\text { Montt }\end{array}$ & 6 & 9 & 5 & 1 & 3 & & 3 & 6 \\
\hline Quellón & 0 & 2 & & & & 2 & 0 & 2 \\
\hline Total & 54 & 30 & 20 & 2 & 4 & 4 & 15 & 15 \\
\hline
\end{tabular}




\section{Discussion}

We were able to successfully identify Atlantic salmon, coho salmon, Chinook salmon, and rainbow trout in the "salmon" sampled from sushi. Similar results have been used to distinguish Atlantic salmon from rainbow trout using PCR-RFLP in mitochondrial (i.e., cyt b, COII, 16S) and nuclear (i.e., 5S) fragments from fresh and smoked samples [47-49]. Although restriction enzymes have been widely used to identify salmonids in the food industry $[40,49]$, to the best of our knowledge, it has not been previously used to identify mislabeling and misnaming of species sold as sushi. Russell et al. [40] also used cyt $b$ to identify ten species of salmonids from samples that had been smoked, cooked, and pickled. Later, Hold et al. [43] subsequently showed the utility and reproducibility of the technique across several European laboratories including validated samples. Our results agree with these previous studies using PCR-RFLP for salmonid identification and extend its use to species identification for salmonid sushi.

To date, several PCR-based methods for fish authentication have additionally been used to PCR-RFLP including random amplified polymorphic DNA, single stranded conformational polymorphism, amplified fragment length polymorphism, and direct sequencing of DNA barcoding [50-52], with advantages and disadvantages associated with the different approaches $[35,53,54]$. The recent sequencing revolution has allowed researchers to go to even greater depths with regard to seafood traceability [55], with genomic tools allowing not only the species, but also population to be identified [56-58]. Although such new technology has much to offer, our results and recent studies published using PCR-RFLP for traceability in other seafood products [59-63] underline the continued use of PCR-RFLP as a cost-effective, fast, and simple means to identify salmonid species and mislabeling at the point of sale.

Atlantic salmon was the most used species in Chilean sushi, reflecting the dominance of the species both globally and in Chile [8]. The bulk of Chilean production of Atlantic salmon is sold for export [9], with the remainder consumed in the domestic market. In our study, at least $60 \%$ of sushi retailers included this species, possibly reflecting a mix of consumer preference for salmon over trout and ease of supply. Among the other three salmonids found in Chilean sushi (coho salmon, rainbow trout, and Chinook salmon), Chinook salmon represents the least expensive option to sushi producers (personal communication by sushi master: Sendai sushi, Temuco, 24 January 2020). At the time of sampling, no Chinook salmon of aquaculture origin were available as aquaculture activities ended in Chile ca. 2009 [12]. As such, Chinook salmon sold in sushi can only have originated from wild-caught individuals from naturalized populations. Chile has several naturalized Chinook salmon populations that spawn in several rivers [12,64-66]. However, only one fishery (the Toltén River artisanal fishery) is authorized by the Chilean government to legally capture and sell Chinook salmon [67]. This fishery is located close to Temuco, where the $5 \%$ of the total sushi samples included Chinook salmon (four of 84). However, given that salespeople were unaware of the origin of Chinook salmon, it is more likely that the product originated via informal channels as Chinook salmon are also illegally captured and commercialized to catering businesses. Unfortunately, the small fragment sequenced here ( $\sim 46 \mathrm{bp})$ to identify species does not have the statistical power to differentiate between populations. However, in the future, genetic studies with a finer resolution could be undertaken to identify the basin of origin of Chinook salmon sold as sushi. To date, two studies at the population level have differentiated individuals from the Toltén River from other rivers in Chile (e.g., single nucleotide polymorphisms, [12]; microsatellites [68]). Use of these two approaches will resolve the issue of which river system the fish originated from, but not whether they were captured in a legal or illegal fishery. It will be important for fishery managers to build an identity for their product that allows it to be recognized in order to counter such problems.

Seafood mislabeling can reflect both fraud or human error in terms of the supply of the product [57] as well as a lack of knowledge at the point of sale. In our sample of Chilean sushi suppliers, the mislabeling rate found was higher than rates published for salmonid products, which ranged from $1 \%$ [43] to $11 \%$ [69], being more similar to those for non-salmon seafood sales worldwide (e.g., 25\%) [29]. 
In the literature, sushi suppliers have been shown to display higher mislabeling rates (10\% to $74 \%)$ compared to restaurant and grocery stores $[18,27,28,70]$. According to Bénard-Capelle et al. [17], the majority of fraud is seen in products purchased from fishmongers, restaurants, and other food outlets. In a Chilean context, mislabeling is due to the substitution of rainbow trout for salmon, at least by Chilean sushi producers. Such issues with mislabeling is also apparent in Chile for non-salmon seafood, such as crustaceans [71] and bivalves [72], even though Chilean labeling regulations require that species names are included in ingredient lists (Chilean Ministry of Health).

Our results highlight a general lack of knowledge by salespersons regarding the species contained in their products. While most of the staff selling sushi were unable to identify a principal ingredient in their product, when an attempt to identify the product was made, it was wrong in half of the cases. There is a clear lack of familiarity with species these outlets are supplying, even from cities where aquaculture is a key economic activity (e.g., Puerto Montt, Quellón; Figure 1).

It is possible that the high mislabeling and misnaming identified here simply reflect a lack of training, interest, or both, by outlet owners and staff at the point of sale. This may result in poor customer service, and may be due to the low wages associated with such work as suggested by Ramírez et al. [73]. We encountered four cases where the product was identified as "salmon-trout". This term was declared in three locations (i.e., Valdivia, Osorno, and Quellón) and samples were identified as Atlantic salmon and rainbow trout. This type of misnaming results in consumer confusion and supports the idea that staff from sushi outlets are likely unaware of what they are selling and poorly trained on salmonid taxonomy. Confusion in staff from sushi outlets may reflect variation in the products supplied (some weeks, salmon; some weeks, trout), and without training of staff by outlet owners at the point of sale, such confusion can be transferred to consumers. It is likely that this confusion partly reflects the use of the "salmon" label for various species within two distinct genera: Oncorhynchus and Salmo [69]. However, most people are unaware of this issue, especially so in Chile where salmonids are non-native species.

\section{Conclusions}

This study used PCR-RFLP to identify "salmon" sold in Chilean sushi outlets. Our results showed that menus and statements from salespeople at the point of sale were inaccurate, with high rates of mislabeled (23\%) and misnamed (18\%) products. We also showed that most salespeople $(64 \%)$ were unable to identify the species they were selling to customers. Finally, we identified the use of naturalized Chinook salmon in sushi. Given the use of uncooked flesh in sushi, this could represent a potential human health issue if from an illegal source; otherwise, if authorized, formalized, certified, and well identified at the point of sale, this could open a valuable market niche for local, naturalized-caught fish, improving the economic opportunity for fishing communities.

Supplementary Materials: The following are available online at http://www.mdpi.com/2304-8158/9/11/1699/s1, Table S1: List of sequences obtained from GenBank used for support in the use of the DdeI restriction enzyme as the salmonid identifier in this study. Table S2: Localities, sushi places sampled along Chile and molecular diagnosis. Figure S1: Virtual gel for the in silico RFLP analysis of the mitochondrial cytochrome $b$ fragment for sequences obtained from GenBank used for support in to use of the DdeI.

Author Contributions: Conceptualization, D.G.-U. and C.B.C.-A.; Methodology, V.P.; Formal analysis, V.P. and C.B.C.-A.; Investigation, V.P.; Resources, M.S., C.Q.-R., C.H., D.G.-U., B.C., and C.B.C.-A.; Data curation, V.P.; Writing-original draft preparation, V.P. and C.B.C.-A.; Writing-review and editing, M.S., C.Q.-R., C.H., and C.B.C.-A.; Supervision, C.B.C.-A.; Project administration, C.B.C.-A.; Funding acquisition, D.G.-U., C.H., and C.B.C.-A. All authors have read and agreed to the published version of the manuscript.

Funding: This work was supported by Proyecto Interno Regular R27/19 Universidad de Los Lagos; and Núcleo Milenio INVASAL funded by Chile's Government program, Iniciativa Científica Milenio from Ministerio de Ciencia, Tecnología, Conocimiento e Innovación.

Acknowledgments: We are thankful to the people who contributed with samples, and sushi places for the information provided. We thank Marzia Pezzolato and two anonymous reviewers for providing valuable comments on earlier drafts of the manuscript. C.B.C.-A. thanks Jose Luis Muñoz for supporting the application to Proyecto Interno Regular R27/19 Universidad de Los Lagos and Fernanda X Oyarzun for insightful discussion 
about this manuscript. C.B.C.-A. is grateful for the computational and laboratory equipment acquired from Fondecyt Iniciación 11180897. C.Q.-R. thanks the Fondecyt Iniciación 11181259.

Conflicts of Interest: The authors declare no conflict of interest.

\section{References}

1. Rembold, C.M. The health benefits of eating salmon. Science 2004, 305, 475. [CrossRef] [PubMed]

2. Mouritsen, O.G. SUSHI Food for the Eye, the Body E the Soul; Springer: Boston, MA, USA, 2009; ISBN 9781441906175.

3. Schlag, A.K. Aquaculture: An emerging issue for public concern. J. Risk Res. 2010, 13, 829-844. [CrossRef]

4. Campbell, H. Breaking new ground in food regime theory: Corporate environmentalism, ecological feedbacks and the 'food from somewhere' regime? Agric. Hum. Values 2009, 26, 309. [CrossRef]

5. DesRivières, C.P.; Chuenpagdee, R.; Mather, C. Reconnecting people, place, and nature: Examining alternative food networks in Newfoundland's fisheries. Agric. Food Secur. 2017, 6, 33. [CrossRef]

6. Le Velly, R.; Dufeu, I. Alternative food networks as "market agencements": Exploring their multiple hybridities. J. Rural Stud. 2016, 43, 173-182. [CrossRef]

7. FDA Guidance for Industry: The Seafood List; Food and Drug Documentation: Rockville, MD, USA, 2020.

8. Berger, T.; Sibeni, F.; Calderini, F. FishStatJ, a Tool for Fishery Statistics Analysis Release: 4.00.15; FAO: Rome, Italy, 2020.

9. Gonzalez-Poblete, E.; Drakeford, B.M.; Ferreira, F.H.; Barraza, M.G.; Failler, P. The impact of trade and markets on Chilean Atlantic salmon farming. Aquac. Int. 2019, 27, 1465-1483. [CrossRef]

10. Arismendi, I.; Soto, D.; Penaluna, B.; Jara, C.; Leal, C.; León-Muñoz, J. Aquaculture, non-native salmonid invasions and associated declines of native fishes in Northern Patagonian lakes. Freshw. Biol. 2009, 54, 1135-1147. [CrossRef]

11. Canales-Aguirre, C.B.; Seeb, L.W.; Seeb, J.E.; Cádiz, M.I.; Musleh, S.S.; Arismendi, I.; Gajardo, G.; Galleguillos, R.; Gomez-Uchida, D. Contrasting genetic metrics and patterns among naturalized rainbow trout (Oncorhynchus mykiss) in two Patagonian lakes differentially impacted by trout aquaculture. Ecol. Evol. 2018, 8, 273-285. [CrossRef]

12. Gomez-Uchida, D.; Cañas-Rojas, D.; Riva-Rossi, C.M.; Ciancio, J.E.; Pascual, M.A.; Ernst, B.; Aedo, E.; Musleh, S.S.; Valenzuela-Aguayo, F.; Quinn, T.P.; et al. Genetic signals of artificial and natural dispersal linked to colonization of South America by non-native Chinook salmon (Oncorhynchus tshawytscha). Ecol. Evol. 2018, 8, 6192-6209. [CrossRef]

13. Colihueque, N.; Vergara, N.; Parraguez, M. Genetic characterization of naturalized populations of brown trout Salmo trutta L. in southern Chile using allozyme and microsatellite markers. Aquac. Res. 2003, 34, 525-533. [CrossRef]

14. Colihueque, N.; Estay, F.J.; Crespo, J.E.; Arriagada, A.; Baessolo, L.; Canales-Aguirre, C.B.; Marín, J.; Carrasco, R. Genetic Differentiation and Origin of Naturalized Rainbow Trout Populations From Southern Chile, Revealed by the mtDNA Control Region Marker. Front. Genet. 2019, 10, 1212. [CrossRef] [PubMed]

15. Hayes, B.; Sonesson, A.K.; Gjerde, B. Evaluation of three strategies using DNA markers for traceability in aquaculture species. Aquaculture 2005, 250, 70-81. [CrossRef]

16. Hu, Y.; Huang, S.Y.; Hanner, R.; Levin, J.; Lu, X. Study of fish products in Metro Vancouver using DNA barcoding methods reveals fraudulent labeling. Food Control 2018, 94, 38-47. [CrossRef]

17. Bénard-Capelle, J.; Guillonneau, V.; Nouvian, C.; Fournier, N.; Le Loët, K.; Dettai, A. Fish mislabelling in France: Substitution rates and retail types. PeerJ 2015, 2, e714. [CrossRef] [PubMed]

18. Vandamme, S.G.; Griffiths, A.M.; Taylor, S.-A.; Di Muri, C.; Hankard, E.A.; Towne, J.A.; Watson, M.; Mariani, S. Sushi barcoding in the UK: Another kettle of fish. PeerJ 2016, 4, e1891. [CrossRef] [PubMed]

19. Gopi, K.; Mazumder, D.; Sammut, J.; Saintilan, N. Determining the provenance and authenticity of seafood: A review of current methodologies. Trends Food Sci. Technol. 2019, 91, 294-304. [CrossRef]

20. Gordoa, A.; Carreras, G.; Sanz, N.; Viñas, J. Tuna Species Substitution in the Spanish Commercial Chain: A Knock-On Effect. PLoS ONE 2017, 12, e0170809. [CrossRef]

21. Crego-Prieto, V.; Campo, D.; Perez, J.; Martinez, J.L.; Garcia-Vazquez, E.; Roca, A. Inaccurate labelling detected at landings and markets: The case of European megrims. Fish. Res. 2012, 129-130, 106-109. [CrossRef]

22. Iglésias, S.P.; Toulhoat, L.; Sellos, D.Y. Taxonomic confusion and market mislabelling of threatened skates: Important consequences for their conservation status. Aquat. Conserv. 2010, 20, 319-333. [CrossRef] 
23. Tantillo, G.; Marchetti, P.; Mottola, A.; Terio, V.; Bottaro, M.; Bonerba, E.; Bozzo, G.; Di Pinto, A. Occurrence of Mislabelling in Prepared Fishery Products in Southern Italy. Ital. J. Food Saf. 2015, 4, 5358. [CrossRef]

24. Gómez Tovar, L.; Martin, L.; Gómez Cruz, M.A.; Mutersbaugh, T. Certified organic agriculture in Mexico: Market connections and certification practices in large and small producers. J. Rural Stud. 2005, 21, 461-474. [CrossRef]

25. Sakamoto, R.; Allen, M. There's something fishy about that sushi: How Japan interprets the global sushi boom. Jpn. Forum 2011, 23, 99-121. [CrossRef]

26. Cwiertka, K. Culinary Culture and the Making of a National Cuisine. In A Companion to the Anthropology of Japan; Robertson, J., Ed.; Blackwell Publishing Ltd.: Malden, MA, USA, 2005; pp. 415-428. ISBN 9780470996966.

27. Khaksar, R.; Carlson, T.; Schaffner, D.W.; Ghorashi, M.; Best, D.; Jandhyala, S.; Traverso, J.; Amini, S. Unmasking seafood mislabeling in U.S. markets: DNA barcoding as a unique technology for food authentication and quality control. Food Control 2015, 56, 71-76. [CrossRef]

28. Willette, D.A.; Simmonds, S.E.; Cheng, S.H.; Esteves, S.; Kane, T.L.; Nuetzel, H.; Pilaud, N.; Rachmawati, R.; Barber, P.H. Using DNA barcoding to track seafood mislabeling in Los Angeles restaurants. Conserv. Biol. 2017, 31, 1076-1085. [CrossRef] [PubMed]

29. Wong, E.H.-K.; Hanner, R.H. DNA barcoding detects market substitution in North American seafood. Food Res. Int. 2008, 41, 828-837. [CrossRef]

30. Acuña, G.; Ortiz-Riaño, E.; Vinagre, J.; García, L.; Kettlun, A.M.; Puente, J.; Collados, L.; Valenzuela, M.A. Application of capillary electrophoresis for the identification of Atlantic salmon and rainbow trout under raw and heat treatment. J. Capill. Electrophor. Microchip Technol. 2008, 10, 93-99. [PubMed]

31. Molkentin, J.; Meisel, H.; Lehmann, I.; Rehbein, H. Identification of organically farmed Atlantic salmon by analysis of stable isotopes and fatty acids. Eur. Food Res. Technol. 2007, 224, 535-543. [CrossRef]

32. Molkentin, J.; Lehmann, I.; Ostermeyer, U.; Rehbein, H. Traceability of organic fish—Authenticating the production origin of salmonids by chemical and isotopic analyses. Food Control 2015, 53, 55-66. [CrossRef]

33. Turujman, S.A.; Wamer, W.G.; Wei, R.R.; Albert, R.H. Rapid liquid chromatographic method to distinguish wild salmon from aquacultured salmon fed synthetic astaxanthin. J. AOAC Int. 1997, 80, 622-632. [CrossRef]

34. Lockley, A.K.; Bardsley, R.G. DNA-based methods for food authentication. Trends Food Sci. Technol. 2000, 11, 67-77. [CrossRef]

35. Mafra, I.; Ferreira, I.M.P.L.V.O.; Oliveira, M.B.P.P. Food authentication by PCR-based methods. Eur. Food Res. Technol. 2008, 227, 649-665. [CrossRef]

36. Rasmussen, R.S.; Morrissey, M.T. DNA-based methods currently employed in the authentication of commercial fish and seafood species. Compr. Rev. Food Sci. Food Saf. 2008, 7, 280-295. [CrossRef]

37. Teletchea, F.; Maudet, C.; Hänni, C. Food and forensic molecular identification: Update and challenges. Trends Biotechnol. 2005, 23, 359-366. [CrossRef] [PubMed]

38. Armani, A.; Tinacci, L.; Lorenzetti, R.; Benvenuti, A.; Susini, F.; Gasperetti, L.; Ricci, E.; Guarducci, M.; Guidi, A. Is raw better? A multiple DNA barcoding approach (full and mini) based on mitochondrial and nuclear markers reveals low rates of misdescription in sushi products sold on the Italian market. Food Control 2017, 79, 126-133. [CrossRef]

39. Araneda, C.; Larraín, M.A.; Hecht, B.; Narum, S. Adaptive genetic variation distinguishes Chilean blue mussels (Mytilus chilensis) from different marine environments. Ecol. Evol. 2016, 6, 3632-3644. [CrossRef]

40. Russell, V.J.; Hold, G.L.; Pryde, S.E.; Rehbein,H.; Quinteiro, J.; Rey-Mendez, M.; Sotelo, C.G.; Pérez-Martin, R.I.; Santos, A.T.; Rosa, C. Use of restriction fragment length polymorphism to distinguish between salmon species. J. Agric. Food Chem. 2000, 48, 2184-2188. [CrossRef]

41. Wolf, C.; Burgener, M.; Hübner, P.; Lüthy, J. PCR-RFLP Analysis of Mitochondrial DNA: Differentiation of Fish Species. LWT Food Sci. Technol. 2000, 33, 144-150. [CrossRef]

42. Burgener, M. Molecular Species Differentiation of Fish and Mammals. Ph.D. Thesis, University of Bern, Bern, Switzerland, 1997.

43. Hold, G.L.; Russell, V.J.; Pryde, S.E.; Rehbein, H.; Quinteiro, J.; Rey-Mendez, M.; Sotelo, C.G.; Pérez-Martin, R.I.; Santos, A.T.; Rosa, C. Validation of a PCR-RFLP based method for the identification of salmon species in food products. Eur. Food Res. Technol. 2001, 212, 385-389. [CrossRef]

44. Miller, S.A.; Dykes, D.D.; Polesky, H.F. A simple salting out procedure for extracting DNA from human nucleated cells. Nucleic Acids Res. 1988, 16, 1215. [CrossRef]

45. Edgar, R.C. MUSCLE: Multiple sequence alignment with high accuracy and high throughput. Nucleic Acids Res. 2004, 32, 1792-1797. [CrossRef] 
46. Everard, M. Britain's Freshwater Fishes; Princeton University Press: Princeton, NJ, USA, 2013.

47. Carrera, E.; García, T.; Cespedes, A.; Gonzalez, I.; Fernandez, A.; Asensio, L.M.; Hernandez, P.E.; Martín, R. Differentiation of smoked Salmo salar, Oncorhynchus mykiss and Brama raii using the nuclear marker $5 \mathrm{~S}$ rDNA. Int. J. Food Sci. Technol. 2000, 35, 401-406. [CrossRef]

48. Carrera, E.; Garcia, T.; Céspedes, A.; González, I.; Fernández, A.; Hernández, P.E.; Martín, R. Salmon and Trout Analysis by PCR-RFLP for Identity Authentication. J. Food Sci. 1999, 64, 410-413. [CrossRef]

49. Carrera, E.; Cespedes, A.; Gonzalez, I.; Sanz, B.; Hernandez, P.E. Identification of Atlantic Salmon (Salmo salar) and Rainbow Trout (Oncorhynchus mykiss) by Using Polymerase Chain Reaction Amplification and Restriction Analysis of the Mitochondrial Cytochrome b Gene. J. Food Prot. 1998, 61, 482-486. [CrossRef] [PubMed]

50. Jin, L.-G.; Long-Guo, J.I.N.; Ji-Young, C.H.O.; Seong, K.-B.; Park, J.-Y.; Kong, I.-S.; Hong, Y.-K. $18 \mathrm{~S}$ rRNA gene sequences and random amplified polymorphic DNA used in discriminating Manchurian trout from other freshwater salmonids. Fish. Sci. 2006, 72, 903-905. [CrossRef]

51. Zhang, J.; Wang, H.; Cai, Z. The application of DGGE and AFLP-derived SCAR for discrimination between Atlantic salmon (Salmo salar) and rainbow trout (Oncorhynchus mykiss). Food Control 2007, 18, 672-676. [CrossRef]

52. Rehbein, $\mathrm{H}$. Identification of the fish species of raw or cold-smoked salmon and salmon caviar by single-strand conformation polymorphism (SSCP) analysis. Eur. Food Res. Technol. 2005, 220, 625-632. [CrossRef]

53. Asensio Gil, L. PCR-based methods for fish and fishery products authentication. Trends Food Sci. Technol. 2007, 18, 558-566. [CrossRef]

54. Fontanesi, L. Genetic authentication and traceability of food products of animal origin: New developments and perspectives. Ital. J. Anim. Sci. 2009, 8, 9-18. [CrossRef]

55. Bernatchez, L.; Wellenreuther, M.; Araneda, C.; Ashton, D.T.; Barth, J.M.I.; Beacham, T.D.; Maes, G.E.; Martinsohn, J.T.; Miller, K.M.; Naish, K.A.; et al. Harnessing the Power of Genomics to Secure the Future of Seafood. Trends Ecol. Evol. 2017, 32, 665-680. [CrossRef]

56. Ogden, R. Fisheries forensics: The use of DNA tools for improving compliance, traceability and enforcement in the fishing industry. Fish Fish. 2008, 9, 462-472. [CrossRef]

57. Stawitz, C.C.; Siple, M.C.; Munsch, S.H.; Lee, Q.; Derby, S.R. Financial and Ecological Implications of Global Seafood Mislabeling: Implications of seafood mislabeling. Conserv. Lett. 2017, 10, 681-689. [CrossRef]

58. Withler, R.E.; Candy, J.R.; Beacham, T.D.; Miller, K.M. Forensic DNA Analysis of Pacific Salmonid Samples for Species and Stock Identification. Environ. Biol. Fishes 2004, 69, 275-285. [CrossRef]

59. Ferrito, V.; Raffa, A.; Rossitto, L.; Federico, C.; Saccone, S.; Pappalardo, A.M. Swordfish or Shark Slice? A Rapid Response by COIBar-RFLP. Foods 2019, 8, 537. [CrossRef] [PubMed]

60. Pappalardo, A.M.; Federico, C.; Saccone, S.; Ferrito, V. Differential flatfish species detection by COIBar-RFLP in processed seafood products. Eur. Food Res. Technol. 2018, 244, 2191-2201. [CrossRef]

61. Pappalardo, A.M.; Petraccioli, A.; Capriglione, T.; Ferrito, V. From Fish Eggs to Fish Name: Caviar Species Discrimination by COIBar-RFLP, an Efficient Molecular Approach to Detect Fraud in the Caviar Trade. Molecules 2019, 24, 2468. [CrossRef]

62. Pappalardo, A.M.; Ferrito, V. A COIBar-RFLP strategy for the rapid detection of Engraulis encrasicolus in processed anchovy products. Food Control 2015, 57, 385-392. [CrossRef]

63. Ferrito, V.; Bertolino, V.; Pappalardo, A.M. White fish authentication by COIBar-RFLP: Toward a common strategy for the rapid identification of species in convenience seafood. Food Control 2016, 70, 130-137. [CrossRef]

64. Becker, L.A.; Pascual, M.A.; Basso, N.G. Colonization of the southern Patagonia Ocean by exotic chinook salmon. Conserv. Biol. 2007, 21, 1347-1352. [CrossRef]

65. Fernández, D.A.; Ciancio, J.; Ceballos, S.G.; Riva-Rossi, C.; Pascual, M.A. Chinook salmon (Oncorhynchus tshawytscha, Walbaum 1792) in the Beagle Channel, Tierra del Fuego: The onset of an invasion. Biol. Invasions 2010, 12, 2991-2997. [CrossRef]

66. Gomez-Uchida, D.; Aedo, G.; Ernst, B.; Canales-Aguirre, C.B.; Ferrada-Fuentes, S.; Cañas, M.; Cañas, D.; Cadíz, M.I.; Musleh, S.; Rivara, P. Estudio Biológico Pesquero y Sanitario de la Población de Salmón Chinook en la Cuenca del río Toltén en la Región de la Araucanía. FIPA 2014-87 2016. Available online: http://www.subpesca.cl/fipa/613/w3-article-89445.html (accessed on 13 November 2020).

67. Subpesca Aprueba Manejo del Salmón Chinook en la Cuenca del río Toltén, IX Región de la Araucania 2018. Available online: http://www.subpesca.cl/portal/615/articles-99933_documento.pdf (accessed on 13 November 2020). 
68. Correa, C.; Moran, P. Polyphyletic ancestry of expanding Patagonian Chinook salmon populations. Sci. Rep. 2017, 7, 14338. [CrossRef]

69. Cline, E. Marketplace substitution of Atlantic salmon for Pacific salmon in Washington State detected by DNA barcoding. Food Res. Int. 2012, 45, 388-393. [CrossRef]

70. Warner, K.; Timme, W.; Lowell, B.; Hirschfield, M. Oceana Study Reveals Seafood Fraud Nationwide; Oceana: Washington, DC, USA, 2013.

71. Haye, P.A.; Segovia, N.I.; Vera, R.; de los Ángeles Gallardo, M.; Gallardo-Escárate, C. Authentication of commercialized crab-meat in Chile using DNA Barcoding. Food Control 2012, 25, 239-244. [CrossRef]

72. Larraín, M.A.; Díaz, N.F.; Lamas, C.; Uribe, C.; Araneda, C. Traceability of mussel (Mytilus chilensis) in southern Chile using microsatellite molecular markers and assignment algorithms. Exploratory survey. Food Res. Int. 2014, 62, 104-110. [CrossRef]

73. Ramírez, C.; Chan, C. Making community under shared conditions of insecurity: The negotiation of ethnic borders in a multicultural commercial neighbourhood in Santiago, Chile. J. Ethn. Migr. Stud. 2020, 46, 2764-2781. [CrossRef]

Publisher's Note: MDPI stays neutral with regard to jurisdictional claims in published maps and institutional affiliations.

(C) 2020 by the authors. Licensee MDPI, Basel, Switzerland. This article is an open access article distributed under the terms and conditions of the Creative Commons Attribution (CC BY) license (http://creativecommons.org/licenses/by/4.0/). 